\title{
Clinical Study of Results of Myringoplasty with Tragal Perichondrium
}

\author{
Srikanth Myla ${ }^{1}$, Ramesh Elma ${ }^{2}$
}

\begin{abstract}
A clinical study was undertaken to evaluate incidence of age, sexin tubotympanic type chronic suppurative otitis media patients admitted in the wardof $s$ s medical college and hospital.Clinical study of pathology(site of perforation), preoperative audiological evaluation in chronic suppurative otitis media patients. Study of surgical procedure(myringoplasty) with tragal perichondrium adopted for treatment for tubotympanic type chronic suppurative otitis media in the patients selected. Post operative foollw up, success rate of graft uptake, hearing improvement results were analysed.
\end{abstract}

Keywords: Chronic suppurative otitis media,central perforation, air bone gap, tragalperichondrium,myringoplasty

\section{Introduction}

The perforation of the tympanic membrane may be of traumatic origin or due to chronic suppurative otitis media.If the perforation fails to heal spontaneously or by conservative therapy, they require surgical closure. The repaired perforation restores the vibratory area of the tympanic membrane and affords round window protection, thus improving hearing.

Chronic otitis media is the most advanced disease state in the spectrum of otitis media and is associated with some form of irreversible pathologic condition in the middle ear such as granulation tissue, ossicular changes, tympanosclerosis,tympanic membrane perforation and cholesteatoma.

Traditionally chronic otitis media is classified into tubo tympanic disease characterised by the presence of a central perforation and atticoantral disease characterised by the presence of attic perforation, marginal perforation with or with out cholesteatoma.

Myringoplasty is the main surgical treatment for tubo tympanic disease. It is defined as an operation performed to eradicate disease in the middle ear and to reconstruct the hearing mechanism without matoid surgery.

Biological graft materials acts as scoffold of tissue matrix when applied to seal the perforation and this subsequently revascularises in readiness for migration of fibroblasts and epithelium. Some of the commonly used autologous graft materials include vein, fat, fascia lata,temporalisfascia,tragal perichondrium and cartilage.However due to it anatomic proximity, translucency and suppleness, temporalis fascia and tragalperichondrium are two most preferred grafting materials.In this study, we have attempted to analyse the tragal perichondrium as the ideal graft material with regards to grafts uptake and hearing improvement in cases of underlay myringoplasty.

\section{Objectives}

We are performing a prospective randomized study with a sample size of 60 patients to evaluate the efficacy of graft material. We are evaluating the underlay myringoplasty using the graft material tragal perichondrium by the criteria of graft uptake rate, hearing improvement and infection rate.

To establish the ideal graft material with regard to graft uptake, hearing improvement.

\section{Materials and Methods}

All patients the ENT outpatient department in S V S hospital, Mahabubnagar between July 2011 and Nnov 2012 with complaints of ear discharge and decreased hearing were screened. Those patients, in whom tubotympanic type of chronic suppurative otitis media was found, were taken up for this prospective study.

This study comprises of 60 patients who were subjected to underlay myringoplasty for the treatment of chronic suppurative otitis media. Each patient was subjected to detail examination of nose, para nasal sinuses and throat to rule out any focus of infection, which could influence the result of myringoplasty. The study was done on following parameters, graft uptake audiological out come(closure air bone gap, sensory neural hearing loss), late complications like reperforation, retraction, adhesions, worsening of air bone gap.

Method of collection of data: cases selected for the study were subjected to detailed history taking and clinical examination of ear, nose and throat was done with special reference to the ear. An otosocpic examination was done to record the site and size of perforation. All findings were confirmed with examination of the ear under microscope.Hearng status was assessed with tuning fork tests ( Rinnes, webers, absolute bone conduction tests), using 256,512,1024 hz tuning forks.Pure tone audiometry performed in the frequencies of 500,1000,2000, and 4000 .

Inclusion criteria: chronic suppurative otitis media tubotympanic type with central perforation of unilateral type,patients both male and females age group from 13 to 56 years,pure tone average between $20-45 \mathrm{db}$ hearing loss, ear to be operated should be without discharge for atleast 4 weeks before surgery, no sensory neural hearing loss, Eustachian tube function should be normal.

Exclusion criteria: Active discharging ear, patient with uncontrolled hypertension, diabetes and severe anemia, 


\section{International Journal of Science and Research (IJSR) \\ ISSN (Online): 2319-7064}

Index Copernicus Value (2013): 6.14 | Impact Factor (2015): 6.391

patient with nose, pns and throat problems are eliminated, bilateral ear discharge, revision myringoplasty, patient $<12$ years $>56$ years

Observations: our study includes follow up of post operative cases for 2 yrs. Out of 60 cases operated 11 cases did not come for follow up.Hence they were excluded. The remaining 49 cases came for follow up were included in the study.

Age distribution: The youngest patient in our study was 13 years old while the oldest patient was 56 year old. The average incidence was 26.6 years.

Table 1: Age distribution

\begin{tabular}{|c|c|c|}
\hline Years & Total Number & Percentage \% \\
\hline $13-20$ & 20 & 40.9 \\
\hline $21-30$ & 19 & 38.9 \\
\hline $31-40$ & 5 & 10.1 \\
\hline$>40$ & 5 & 10.1 \\
\hline TOTAL & 49 & 100 \\
\hline
\end{tabular}

Sex distribution: The overall male to female ratio was 27.22. Among patients undergoing surgery $55 \%$ were males, $45 \%$ were females.

Table 2: Sex distribution

\begin{tabular}{|c|c|c|}
\hline Sex & Total Number & Percentage\% \\
\hline Males & 25 & 55 \\
\hline Females & 22 & 45 \\
\hline Total & 49 & 100 \\
\hline
\end{tabular}

Site of tympanic membrane perforation: Of the patients undergoing surgery $38.7 \%$ had anterior quadrant perforation while $8.3 \%$ had posterior quadrant perforation, $53 \%$ had both quadrant perforations.

Table 3: Site of Tympanic Membrane Perforation

\begin{tabular}{|c|c|c|}
\hline Quadrant & Total Number & Percentage\% \\
\hline Anterior & 19 & 38.7 \\
\hline Posterior & 4 & 8.3 \\
\hline Both & 26 & 53 \\
\hline Total & 49 & 100 \\
\hline
\end{tabular}

Pre operative air-bone gap: patients who underwent surgery $30.6 \%$ had $25 \mathrm{db}$ while $40.8 \%$ had 30 dbgap and $28.6 \%$ had more than $30 \mathrm{db}$ air bone gap.

Table 4: Pre Operatve Air Bone Gap

\begin{tabular}{|c|c|c|}
\hline Pure Tone Average $(D B)$ & Total Number & Percentage\% \\
\hline $20-25$ & 15 & 30.6 \\
\hline $26-30$ & 20 & 40.8 \\
\hline$>30$ & 14 & 28.6 \\
\hline Total & 49 & 100 \\
\hline
\end{tabular}

Post operative air bone gap: patients underwent surgery $90 \%$ had a gap of $20 \mathrm{db}$ while $10 \%$ had agap of $>20 \mathrm{db}$.

Table 5: Post Operative Air Bone Gap

\begin{tabular}{|c|c|c|}
\hline Air Bone Gap Closure & Total Number & Percentage \\
\hline$<10$ & 36 & 73 \\
\hline $10-20$ & 8 & 16.3 \\
\hline$>20$ & 5 & 10.7 \\
\hline TOTAL & 49 & 100 \\
\hline
\end{tabular}

Post operative graft status: The graft uptake rate was $83.6 \%$. pinhole size perforation located anteriorly was seen in 11 cases, 4 perforations healed after 2 weeks with chemical cautery. Persistent perforation is seen in 7 cases.

Table 6: Post Operative Graft Status

\begin{tabular}{|c|c|c|}
\hline Graft Status & Total Number & Percentage \\
\hline Intact & 42 & 83.6 \\
\hline Persistent Perforation & 7 & 16.4 \\
\hline Total & 49 & 100 \\
\hline
\end{tabular}

Post operative subjective hearing assessment: $65 \%$ patients who underwent surgery had significant improvement in hearing while $20 \%$ patients had mild hearing improvement, $15 \%$ patients had no hearing improvement.

Table 7: Post Operative Subjective Hearing Assessment

\begin{tabular}{|c|c|c|}
\hline Hearing Assessment & Total Number & Percentage \\
\hline Significant Improvement & 32 & 65 \\
\hline Mild Improvement & 10 & 20 \\
\hline No Change & 7 & 15 \\
\hline Worsened & 0 & 0 \\
\hline Total & 49 & 100 \\
\hline
\end{tabular}

\section{Discussion}

Age incidence: The youngest patient inour study was 13 years old while the oldest patient was 56 years old.The average age incidence was 26.6 years. A study conducted by Jyothidhabolkar also corresponded with the same age group.In the study conducted by Anand et al the average age was 26 years.

Sex incidence: The overall male to female ratio in our study was 55:45.In Jyothidhabolkar study the ratio was 66:34 and Anand group the ratio was 60:40.Though the overall male to female ratio was consistent with other studies.

Sie of perforation: Of the patients undergoing surgery $38.7 \%$ had anterior quadrant perforations, $8.3 \%$ patients had posterior quadrant perforations, $53 \%$ patient had both quadrant perforations.In our study both the quadrant perforations are equivalent to moderate and large perforations.

Graft uptake: The graft uptake rate $83.6 \%$ in our study. Varoius studies showed the graft uptake was in the ratio of $80-90 \%$. Abraham eviator noted that graft uptake rate with tragal perichondrium was $90.47 \%, \mathrm{~T} \mathrm{~S}$ Anand et al observed graft takeup rate of $90 \%$ with hearing improvement $85 \%$. The present study graft uptake rate is reasonably comparable with other authors.

Hearing results: $90 \%$ patients who underwent surgery had a air bone gap more than $20 \mathrm{db}$. Taking post operative air bone gap as the criteria, our study results shows that tragal perichondrium myringoplasty gives better results. A study was conducted by John L Dorn hoffer, the hearing results using tragal perichondrium grafts, out of 22 patients who underwent surgery, the graft was taken up in all the patients and average air bone gap was $6.8 \mathrm{db}$ in the post operative period.In our study post operative $73 \%$ patients had air bone gap of $<10 \mathrm{db}$. The present study graft uptake rate is 


\section{International Journal of Science and Research (IJSR) \\ ISSN (Online): 2319-7064}

Index Copernicus Value (2013): 6.14 | Impact Factor (2015): 6.391

reasonably comparable with other authors, tragal cartilage perichondrium graft used appears stiff and thick, but allows good sound conduction and hence gratifying post operative hearing results.

\section{Conclusions}

Myringoplasty is effective surgery in tubotympanic disease, for control of the disease as well as in improvement of hearing. Taking post operative puretone average as the criterion, tragal perichondrium gives better results in hearing improvement. The results of myringoplasty with tragal perichondrium is very good, when graft uptake is concerned. Tragal perichondrium appers to be a better alternative to other grafts like temporalis fascia.

\section{Acknowledgement}

Dr Srikanth Myla, Professor of ENT, s v s medical college,yenugonda, Mahaboobnagar,Telanganastate,India.

Dr Ramesh Elma,Seniorresident,s v s medical college, yenugonda ,Mahaboobnagar,Telangana state, India.

\section{References}

[1] Abraham Eviator: Tragal perichondrium and cartilage in reconstructive ear surgery; Laryngoscope No,11;88;1-23.

[2] John L. Dornhoffer. Hearing results with cartilage tympanopalsty;Laryngoscope;1997 Aug;107(8);1094-9.

[3] Goodhill V. Harris I.andBrockmann S.J.(1964): Tympanoplasty with perichondrial graft; Archieves of otolaryngology;79:131-137.

[4] Jyothi P. Dobhalkar, Krishnavora, Abhiksikdar(2007); comparative study of under tympanoplasty with temporalis fascia and tragal perichondrium, I. J. O. Head neck surg(April-June 2007);59,116-119.

[5] Qurishi M.S, N.S. Jones(1995): Day care myringoplasty using tragal perichondrium; Clinical Otolaryngology;20:12-14.

[6] Anand T.S, Geethakathuria, Sandeepkumar, Vikramwadhwa, Tapaswinipradhan(2002)I.J.O. and HNS vol.54;No.1,(January-March 2000) 